\title{
First Human Infection of Avian Influenza A(H5N6) Virus Reported in Lao People's Democratic Republic, February-March 2021
} \author{
and Phonepadith Xangsayarath ${ }^{7}$ \\ ${ }^{1}$ Ministry of Health \\ ${ }^{2}$ World Health Organization \\ ${ }^{3} \mathrm{CDC}$ \\ ${ }^{4}$ Luang Prabang Provincial Health Department \\ ${ }^{5}$ Centers for Disease Control and Prevention \\ ${ }^{6}$ Ministry of Agriculture and Forestry \\ ${ }^{7}$ National Center for Laboratory and Epidemiology
}

Bounthanom Sengkeopraseuth ${ }^{1}, \mathrm{Kim} \mathrm{Co}^{2}$, Phetdavanh Leuangvilay ${ }^{2}$, Joshua Mott ${ }^{3}$, Bounyasith Khongsamphanh ${ }^{4}$, Virasack Som Oulay ${ }^{1}$, Reiko Tsuyuoka ${ }^{2}$, May Chiew ${ }^{2}$, Pakapak Ketmayoon ${ }^{2}$, Joyce Jones ${ }^{5}$, Elizabeth Pusch ${ }^{5}$, Yunho Jang ${ }^{5}$, John Barnes ${ }^{3}$, C. Todd Davis ${ }^{3}$, Phouvong Phommachanh ${ }^{6}$, Bouaphanh Khamphaphongphane ${ }^{1}$, Sonja Olsen ${ }^{5}$,

October 24, 2021

\begin{abstract}
In March 2021, Lao People's Democratic Republic (Laos) reported an avian influenza A(H5N6) virus infection in a 5-yearold child identified through sentinel surveillance. This was the first human A(H5N6) infection reported outside of China. A multidisciplinary investigation undertook contact tracing and enhanced human and animal surveillance in surrounding villages and live bird markets. Seven Muscovy ducks tested positive for highly pathogenic avian influenza A(H5N6) viruses. Sequenced viruses belonged to clade 2.3.4.4h and were closely related to viruses detected in poultry in Vietnam, and to previous viruses detected in Laos. Surveillance and coordinated outbreak response remain essential to global health security.
\end{abstract}

\section{Hosted file}

IORV brief report H5N6_10-19-21.docx available at https://authorea.com/users/442668/articles/ 542877-first-human-infection-of-avian-influenza-a-h5n6-virus-reported-in-lao-people-sdemocratic-republic-february-march-2021 